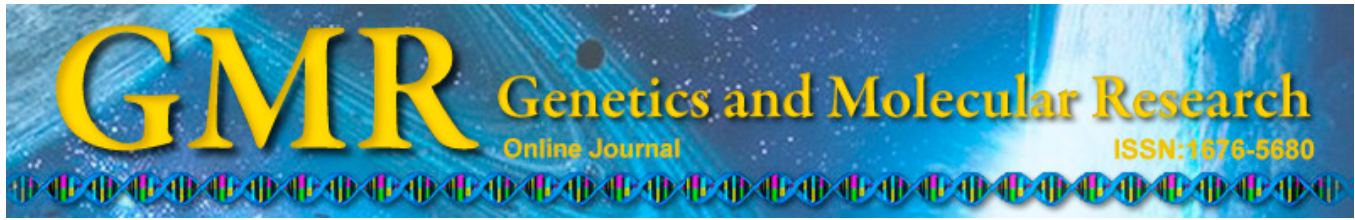

\title{
Aggressiveness of Pseudocercospora griseola strains in common bean genotypes and implications for genetic improvement
}

\author{
R. Pereira ${ }^{1}$, E.A. Souza ${ }^{1}$, Q.L. Barcelos ${ }^{2}$, A.F.B. Abreu ${ }^{1}$ and S.S. Librelon ${ }^{1}$ \\ ${ }^{1}$ Departamento de Biologia, Universidade Federal de Lavras, \\ Lavras, MG, Brasil \\ ${ }^{2}$ Instituto de Ciências Agrárias e Ambientais, \\ Universidade Federal de Mato Grosso, Sinop, MT, Brasil \\ Corresponding author: E.A. Souza \\ E-mail: easouza@dbi.ufla.br
}

Genet. Mol. Res. 14 (2): 5044-5053 (2015)

Received July 18, 2014

Accepted December 10, 2014

Published May 12, 2015

DOI http://dx.doi.org/10.4238/2015.May.12.7

\begin{abstract}
The fungus Pseudocercospora griseola, the causal agent of angular leaf spot in the common bean (Phaseolus vulgaris L.), exhibits a broad pathogenic variability that complicates the development of resistant cultivars. For breeding programs to successfully obtain common bean cultivars with durable resistance, knowing the aggressiveness of different strains, as well as the mechanisms of genetic resistance, is important. The aims of this study were to study the variation within race 63.63 by evaluating the aggressiveness of different strains, to analyze the genetic resistance of common bean lines to $P$. griseola, and to ascertain the implications for genetic improvement in obtaining resistance in this pathosystem. Four strains, collected from different locations, were inoculated in three groups of common bean lines in a greenhouse, and the severity of the disease was subsequently evaluated. Statistical analyses were carried out using the diallel method, which provided information on the vertical and horizontal resistance of host plants, in addition to information
\end{abstract}


regarding the aggressiveness of the strains. The aggressiveness of P. griseola differed between the strains of race 63.63. The diallel method proved to be promising for the identification of horizontal and vertical resistance in the common bean- $P$. griseola pathosystem, with a predominance of horizontal resistance. Gene pyramiding, using marker-assisted selection, may not be the most effective strategy for obtaining durable resistance.

Key words: Common bean; Pseudocercospora griseola; Genetic resistance; Diallel method

\section{INTRODUCTION}

The common bean (Phaseolus vulgaris L.) is widely grown in tropical and subtropical countries, and is an important source of proteins, carbohydrates, fiber, vitamins, and minerals, particularly for people on low incomes (Akond et al., 2011). Its high nutritional value and high rate of consumption make the common bean an important food for many people in developing countries in Africa, Asia, and Latin America (Beebe, 2010).

In spite of its importance, its average yield in developing countries is $0.5 \mathrm{t} / \mathrm{ha}$, which is much lower than the productive potential of the crop (Fao, 2011). Low production is largely due to the negative effects of many biotic and abiotic factors that limit the genetic potential of the crop (Singh and Schwartz, 2010). Among the biotic factors, angular leaf spot, caused by the fungus Pseudocercospora griseola, stands out as one of the main diseases that affects the crop (Sanglard et al., 2006; Singh and Schwartz, 2010; Borel et al., 2011). This disease mainly infects leaves and pods where the pathogen induces premature leaf dropping, and leads to a reduction in grain quality (Mahuku et al., 2009; Borel et al., 2011). There may be up to $80 \%$ yield reduction when environmental conditions are favorable for the development of the pathogen and susceptible cultivars are used (Garcia et al., 2006; Singh and Schwartz, 2010).

Of the control measures used against the disease, genetic resistance has been the most effective, because it reduces the need for agricultural chemicals that contaminate the environment, and reduces production costs. Nevertheless, attaining durable resistance continues to be a challenge for breeders and phytopathologists in most pathosystems (Mundt and Leonard, 1985). Durable resistance depends on factors such as genetic inheritance, variability in the pathogen population, and the utilization strategies of resistance alleles in the host, and should therefore be taken into account by breeders (Adugna, 2004).

A pathogen's ability to cause disease in cultivars of a single host plant is defined as a race. The existence of races is a complication in breeding programs, because cultivars may be resistant to certain races and susceptible to others. P. griseola has great variability, which explains the large number of existing races and the complexity of genetic resistance (Mahuku et al., 2002; Sartorato, 2002; Damasceno-Silva et al., 2008). In addition, in Brazil, most of the strains have been classified as race 63.63, which overcomes the resistance of all the cultivars of the differential group (Balbi et al., 2009; Pereira et al., 2013). However, no studies have been conducted on the existence of variability in aggressiveness among the strains of race 63.63 . 
Co-evolution between pathogens and hosts should be reflected in breeding programs that aim to obtain cultivars resistant to angular leaf spot. Resistance alleles of cultivars of the Mesoamerican gene pool are effective when transferred to Andean cultivars, in regions where strains of Andean origin are prevalent. Consequently, an effective strategy for obtaining improved cultivars is the development of cultivars with resistance genes from both gene pools (Miklas et al., 2006; Singh and Schwartz, 2010).

According to Vanderplank (1963), resistance may be classified as vertical or horizontal, according to its effectiveness against races, and it is possible to identify the type of resistance by means of the significance of the cultivar $\mathrm{x}$ race interaction. This may be seen when a series of different strains of a pathogen is inoculated in different cultivars of a host. In this case, a highly significant cultivar $\mathrm{x}$ race interaction suggests that the reaction of each cultivar is specific to a particular race, indicating that resistance is vertical. For non-significant interactions, the cultivars behave in a similar way to all races; in this case, it may be inferred that resistance is horizontal. Melo and Santos (1999) developed an efficient methodology that is able to provide information about vertical and horizontal resistance of the host, as well as the aggressiveness of the strains of the pathogen. This methodology has already been used in various other pathosystems, as it can identify both horizontal and vertical resistance (Davide and Souza, 2009; Buiate et al., 2010).

Studies of the genetic control of common bean resistance to angular leaf spot have been undertaken, and have mainly reported the presence of vertical resistance (Sartorato et al., 2000; Chataika et al., 2010; Vidigal et al., 2010; Borel et al., 2011). However, horizontal resistance has also been observed in some studies (Amaro et al., 2007; Mahuku et al., 2009; Arantes et al., 2010; Oblessuc et al., 2012). Amaro et al. (2007) investigated variability among common bean lines over five recurrent selection cycles for resistance to angular leaf spot, and they observed different severities of symptoms among the lines considered to be resistant. This was attributed to environmental effects, suggesting that this trait is polygenically controlled. Therefore, it may be inferred that, in addition to genes of large effect (specific resistance), genes of lesser effect, or modifiers, are involved, influenced by the environment, suggesting that the reaction to angular leaf spot exhibits quantitative inheritance (Nelson, 1978; Mahuku et al., 2009). However, no studies have been conducted that have investigated the main mechanism of genetic resistance in the $P$. griseola-common bean pathosystem. The main breeding strategies with a view toward durable resistance to $P$. griseola have considered only vertical resistance, particularly by the pyramiding of genes from backcrosses, with the help of marker-assisted selection (Miklas et al., 2006; Ragagnin et al., 2009; Singh and Schwartz, 2010; Gonçalves-Vidigal et al., 2011).

Therefore, the aims of this study were to study variation within race 63.63 by investigating the aggressiveness of different strains, to analyze genetic resistance (vertical and horizontal) of common bean cultivars to $P$. griseola, and to ascertain the implications for genetic improvement in obtaining durable resistance in this pathosystem.

\section{MATERIAL AND METHODS}

\section{Origin of strains and preparation of suspensions}

Four strains of race 63.63 were collected from different locations in Minas Gerais, 
Brazil, in 2011 and taken to the fungi collection of the Plant Disease Resistance Laboratory of the Biology Department, University of Lavras (Table 1).

\begin{tabular}{lll}
\multicolumn{2}{|c}{ Table 1. Description of the strains of Pseudocercospora griseola evaluated. } \\
\hline Strain & Common bean line & \\
\hline Psg-1 & MAI-18-13 & Origin \\
Psg-2 & Carioca & Patos de Minas \\
Psg-3 & BRSMG-Talismã & Lambari \\
Psg-4 & BRSMG-Madrepérola & Patos de Minas \\
\hline
\end{tabular}

The strains were cultured on leaf dextrose agar medium, and kept at $24^{\circ} \mathrm{C}$ in an incubator (Biochemical Oxygen Demand) for a period of 7 to 10 days with a 12-h photoperiod to obtain spores. The inoculum was prepared by the addition of $5-10 \mathrm{~mL}$ sterile distilled water to each Petri dish, and the surface of the culture was scraped with the aid of a brush to release the conidia. A conidium suspension was obtained by filtering the culture through a layer of cheesecloth to remove mycelial fragments. Conidium counting was performed in a Neubauer chamber to standardize the concentration of the inoculum to $2 \times 10^{4}$ conidia $/ \mathrm{mL}$.

\section{Pathogenicity tests}

Inoculations were carried out in three distinct groups of lines: in differential cultivars, in commercial lines (including two resistant controls), and in lines derived from different cycles of a recurrent selection program (Genetic Improvement Program of the UFLA/Embrapa) for resistance to angular leaf spot. For each isolate, an experiment was conducted with a randomized block design with three replications. One plot consisted of a pot containing the substrate Plantmax $^{\circledR}$ in which four seeds were sown. After the full expansion of the trifoliate leaves of the plants, the spore suspensions were inoculated through spraying on both surfaces of the leaves up to the point of runoff. After the inoculations, the plants were kept in a moist chamber with a relative humidity of $95 \%$, a temperature of around $24^{\circ} \mathrm{C}$, and a 12 -h photoperiod, for about 72 $\mathrm{h}$. The plants were then transferred to a greenhouse, where they remained for 15 days up to the time of evaluation. Disease severity was visually evaluated 18 days after inoculation, using 9 scores as proposed by Pastor-Corrales and Jara (1995): 1, plants without disease symptoms; 2, the presence of up to $3 \%$ leaf lesions; 3 , the presence of up to $5 \%$ leaf lesions, without sporulation of the pathogen; 4 , the presence of sporulating lesions covering $10 \%$ of the leaf area; 5 , the presence of various sporulating lesions from 2 to $3 \mathrm{~mm}$ in size, covering $10-15 \%$ of the leaf area; 6 , the presence of numerous sporulating lesions greater than $3 \mathrm{~mm}$ in size, covering 15 $20 \%$ of the leaf area; 7 , the presence of numerous sporulating lesions greater than $3 \mathrm{~mm}$ in size, covering $20-25 \%$ of the leaf area; 8 , the presence of numerous sporulating lesions greater than $3 \mathrm{~mm}$ in size, covering $25-30 \%$ of the leaf area; and 9, severe symptoms of the disease, resulting in early leaf drop and plant death. The plants that exhibited scores 1 to 3 were considered resistant, and those with scores 3.1 or above were considered susceptible.

\section{Data analysis}

Individual analyses of variance of the mean scores of all the lines were conducted using SAS (SAS Institute, 2000) separately for each isolate: for the differential cultivars, the 
commercial lines, and for those derived from the recurrent selection program. Subsequently, each group of lines inoculated with the four strains was analyzed. Based on these results, a partial diallel analysis was conducted (Melo and Santos, 1999) to obtain estimates of general resistance ability (GRA), general aggressiveness ability (GAA), and specific interaction ability (SIA), using model IV from Griffing (1956).

Diallel analyses were carried out according to the following statistical model:

$$
Y_{i j}=\mu+r_{i}+a_{j}+s_{i j}+e_{i j}
$$

where $y_{i j}$ represents the severity of the disease exhibited by host $i$ when inoculated with isolate $j, r_{i}$ represents the effect of the GRA of the host $i(\mathrm{RH}), a_{j}$ represents the effect of the GAA of isolate $j(\mathrm{AH}), s_{i j}$ represents the effect of the SIA of host $i$ inoculated with isolate $j(\mathrm{RV})$, and $e_{i j}$ represents the mean experimental error.

Estimates of GRA, GAA, and SIA were tested using the Student $t$-test at 1 and $5 \%$ probability, according to the expressions in Ramalho et al. (1993).

\section{RESULTS}

\section{Evaluation of genetic resistance of the differential cultivars of $P$. vulgaris to $P$. griseola}

Based on the results obtained in the diallel analysis (Table 2), it was observed that all of the sources of variation, including the SIA, were statistically significant $(\mathrm{P}<0.05)$. We found that $72.9 \%$ of the total sum of squares of the observed variation was due to the GRA.

\begin{tabular}{|c|c|c|}
\hline SV & d.f. & MS \\
\hline \multicolumn{3}{|c|}{ Differential cultivars } \\
\hline Combinations & 51 & $0.8259 * *$ \\
\hline GRA (RH) & 12 & $2.5587 * *$ \\
\hline GAA (AH) & 3 & $0.4146^{*}$ \\
\hline SIA (RV) & 36 & $0.2826 *$ \\
\hline Error & 102 & 0.1650 \\
\hline Mean & 4.46 & \\
\hline \multicolumn{3}{|l|}{ Cultivars } \\
\hline Combinations & 47 & $1.3116^{* *}$ \\
\hline GRA (RH) & 11 & $2.5684 * *$ \\
\hline GAA (AH) & 3 & $6.1215 * *$ \\
\hline SIA (RV) & 33 & 0.4554 \\
\hline Error & 94 & 0.4806 \\
\hline Mean & 4.98 & \\
\hline \multicolumn{3}{|l|}{ Breeding lines } \\
\hline Combinations & 71 & $0.6759 * *$ \\
\hline GRA (RH) & 17 & $0.8780^{* *}$ \\
\hline GAA (AH) & 3 & $2.8949 * *$ \\
\hline SIA (RV) & 51 & $0.4779 * *$ \\
\hline Error & 142 & 0.2240 \\
\hline Mean & 3.97 & \\
\hline
\end{tabular}


The estimates of the GRA $\left(g_{\mathrm{i}}\right)$ for the different cultivars were significantly different (Table 3). The cultivars Amendoin, G11796, G5686, and México 54 were the most resistant, whereas the cultivars Don Timóteo, Pan 72, and G2858 were the most susceptible, i.e., they exhibited the highest estimates of the GRA $\left(g_{i}\right)$.

\begin{tabular}{|c|c|c|c|}
\hline \multicolumn{4}{|c|}{ Differential cultivars } \\
\hline Andean & Estimate $\left(g_{i}\right)$ & Mesoamerican & Estimate $\left(\mathrm{g}_{\mathrm{i}}\right)$ \\
\hline Don Timóteo & $0.5531^{* *}$ & Pan 72 & $0.9105^{* *}$ \\
\hline G11796 & $-0.7519^{* *}$ & G2858 & $0.9106^{* *}$ \\
\hline Bolón Bayo & $0.3831^{*}$ & Flor de Mayo & -0.0344 \\
\hline Montcalm & $-0.5719^{* *}$ & México 54 & $-0.7219^{* *}$ \\
\hline Amendoin & $-0.8394 * *$ & BAT 332 & -0.2019 \\
\hline G5686 & $-0.7544 * *$ & Cornel149-242 & $-0.4919^{* *}$ \\
\hline Rosinha & $1.6105^{* *}$ & & \\
\hline \multicolumn{4}{|c|}{ Cultivars } \\
\hline Cultivars & Estimate $\left(g_{i}\right)$ & Cultivars & Estimate $\left(\mathrm{g}_{\mathrm{i}}\right)$ \\
\hline Ouro Negro & -0.1233 & Carioca MG & $1.1817^{* *}$ \\
\hline M-20 & -0.5183 & Pérola & -0.0383 \\
\hline Jalo & $1.0267^{* *}$ & Cornell 49242 & $-0.7658^{*}$ \\
\hline Madrepérola & $0.9867 * *$ & AND-277 & $-1.0358^{* *}$ \\
\hline Rosinha & $0.8517 * *$ & MA-16 & -0.2083 \\
\hline Majestoso & $-0.7308^{*}$ & Horizonte & $-0.6258^{*}$ \\
\hline \multicolumn{4}{|c|}{ Breeding lines } \\
\hline Breeding lines & Estimate $\left(\mathrm{g}_{\mathrm{i}}\right)$ & Breeding lines & Estimate $\left(\mathrm{g}_{\mathrm{i}}\right)$ \\
\hline MAI-8.9 & -0.0708 & MAI 6.10 & $-0.4958^{*}$ \\
\hline MAII-10 & -0.0208 & MAII-8 & $0.7292 * *$ \\
\hline MAIII-16.155 & $-0.5958^{* *}$ & MAIII- 16.159 & $-0.7208^{* *}$ \\
\hline MAIV-15.204 & -0.2208 & MAIV-15.203 & 0.0292 \\
\hline MAV-3.36 & -0.0458 & MAV-7.85 & 0.2792 \\
\hline MAVI-24 & 0.3542 & MAVI-21 & 0.3542 \\
\hline MAVII-34 & $-0.4458^{*}$ & MAVII-92 & 0.0792 \\
\hline MAVIII-78 & -0.2958 & MAVIII-94 & $-0.4458^{*}$ \\
\hline Pérola & $0.8292 * *$ & Carioca MG & $0.7292 * *$ \\
\hline
\end{tabular}

** and *Significant at 1 and 5\% probability, respectively, by the Student $t$-test.

\section{Evaluation of genetic resistance of the commercial cultivars of $P$. vulgaris to $P$. griseola}

Based on the results obtained in the diallel analysis (Table 2), it was observed that all of the sources of variation, except for the SIA, were statistically significant $(P<0.01)$. The GRA was predominant, corresponding to $45.83 \%$ of the total sum of squares of the variation observed.

The estimates of GRA $\left(\mathrm{g}_{\mathrm{i}}\right)$ for the cultivars were significantly different (Table 3 ). The cultivars AND-277, Cornell 49242, and Majestoso were the most resistant, while Carioca MG, Jalo, Rosinha, and Madrepérola were the most susceptible.

\section{Evaluation of genetic resistance of the breeding lines of $P$. vulgaris to $P$. griseola}

A summary of the results of the diallel analysis, including the lines of the different recurrent selection cycles and the strains of $P$. griseola, is presented in Table $2 ; 31.29 \%$ and $50.80 \%$ of the total sum of squares of the variation was due to the GRA and the specific resistance ability, respectively. 
Estimates of the GRA ( $\left.g_{j}\right)$ for the lines were significantly different (Table 3). The line cycles III (MAIII-16.155 and MAIII-16.159) and VIII (MAVIII-78 and MAVIII-94) exhibited lower estimates of the GRA, and, therefore, were the most resistant. Table 4 presents the differences in aggressiveness among the strains of race 63.63. The isolate Psg-2 was the most aggressive, while Psg-1 was the least aggressive.

\begin{tabular}{|c|c|c|c|}
\hline \multirow[t]{2}{*}{ Strain } & \multicolumn{3}{|c|}{ Estimates (GAA) } \\
\hline & Differential lines & Cultivars & Breeding lines \\
\hline Psg-1 & $-0.2013 *$ & $-1.0308 * *$ & $-0.2042^{*}$ \\
\hline Psg-2 & $0.1671 *$ & 0.1558 & $0.5458 * *$ \\
\hline Psg-3 & -0.0983 & $0.6117^{* *}$ & $-0.3764 * *$ \\
\hline Psg-4 & 0.1325 & 0.2633 & 0.0347 \\
\hline
\end{tabular}

** and *Significant at 1 and 5\% probability, respectively, by the Student $t$-test.

\section{DISCUSSION}

The strains used in this study were classified as belonging to race 63.63 according to the P. griseola race determination system (Habgood, 1970). However, the GRA estimates (Table 4) were significantly different between the strains, which exhibited different degrees of severity in all of the groups of common bean genotypes evaluated, demonstrating the variability within race 63.63 . This is the first report of the occurrence of pathogenic variation within a single race in this pathosystem. Information on the aggressiveness of the strains is important, not only for knowledge of the variability of the pathogen, but also to assist breeders in the selection of the best genotypes for different geographical regions.

Pathogenic variability between $P$. griseola strains has been reported previously, with race 63.63 being the most frequently investigated (Damasceno-Silva et al., 2008; Balbi et al., 2009). However, due to the variability within this race, there may be different races within that classified as 63.63. The isolate Psg-1 exhibited the lowest aggressiveness in this study (Table 4), which suggests that it contains a greater number of avirulence alleles than do the other isolates, and may belong to another race not detected by the current set of differential cultivars.

The significances of the general combining ability and the cultivar $\mathrm{x}$ isolate interaction (SIA) at low magnitude (Table 2) indicates the predominance of horizontal genetic resistance (Parlevliet, 1981). However, vertical genetic resistance was also detected in this study. Indeed, the lines MAIII-16.155, MAI 6.10, MAVII-34, and MAIII-16.159 had mean scores of less than three for some of the strains evaluated, indicating complete or vertical genetic resistance. In studies of the genetic control of resistance to angular leaf spot, the occurrence of genes of greater effect (vertical resistance) (Sartorato et al., 2000; Chataika et al., 2010; Vidigal et al., 2010; Borel et al., 2011) and horizontal resistance (Amaro et al., 2007; Mahuku et al., 2009; Arantes et al., 2010; Oblessuc et al., 2012) has been reported. Therefore, the use of differential cultivars and the race identification system (Habgood, 1970) is questionable, since the use of these methodologies applies to pathosystems in which vertical resistance predominates. Therefore, the use of differential cultivars and race identification would be unnecessary for angular leaf spot. However, as this system is widely used by researchers, and there are genes of greater effect, the adaptation of differential cultivars would be necessary, so that 
variability within race 63.63 can be detected. This strategy has been proposed for anthracnose in the common bean for the detection of variability within races 65 and 81 of Colletotrichum lindemuthianum (Ishikawa et al., 2011).

The vertical resistance found in this study for the lines cited above (derived from the recurrent selection program) may be explained by different genes of greater effect for resistance that are present in some of the parents that gave rise to the base population (Amaro et al., 2007). Several of these genes have already been described in the literature (Mahuku et al., 2009; Chataika et al., 2010; Borel et al., 2011). Therefore, these lines may be used to increase the set of differential cultivars in order to detect variability within race 63.63.

The differential cultivars G5686, Amendoin, and México 54 exhibited the lowest scores for the severity of angular leaf spot. This result supports previous results, in which these cultivars are frequently cited as possible sources of resistance to be used in breeding programs, with a view toward resistance to angular leaf spot (Jara et al., 2001; Amaro et al., 2007; Arantes et al., 2010). Some inferences may be made in respect to pathogen-host coevolution, based on our results. The strains used in this study are probably of Mesoamerican origin, since they were able to infect Andean and Mesoamerican cultivars. This demonstrates that it is necessary to obtain cultivars with resistance genes from both gene pools in order to obtain durable resistance (Miklas et al., 2006). The cultivars Cornell 49242 and AND 277 exhibited a moderate level of resistance, in contrast with other studies that have found a high level of resistance in these cultivars (Busogoro et al., 1999; Sartorato, 2002). Therefore, the results of the present study lay emphasis on high aggressiveness of strains used in comparison with the previously cited studies.

The cultivars Ouro Negro and Majestoso are adapted to Brazil, and have been reported by many studies as good sources of resistance to P. griseola (Ramalho et al., 2007; Sartorato, 2007). However, in the present study, these lines presented resistance to only one of the strains used. Moreover, various workers have suggested that most of the lines used in Brazil are susceptible, or have low resistance, to $P$. griseola, mainly due to the broad pathogenic variability presented by the pathogen (Garcia et al., 2006; Damasceno-Silva et al., 2008).

Our results show that the vertical genes found in the sources of resistance mentioned above, and also in the cultivars Mexico 54 and BAT 332, were overcome by the $P$. griseola strains evaluated. Considering that the genes with greater effect present in these cultivars are not more effective for conferring resistance to the most frequent race of the pathogen, the pyramiding of such genes by means of marker-assisted selection (Miklas, 2006; Ragagnin et al., 2009; Singh and Schwartz, 2010; Gonçalves-Vidigal et al., 2011) for obtaining durable resistance to the pathogen is debatable.

Our study has revealed that recurrent selection can fix alleles that confer both types of resistance. This breeding method has the advantage of allowing the introduction of sources of resistance with both vertical and horizontal resistance alleles at any stage of recombination, optimizing the search for durable resistance in this pathosystem. It should be highlighted that the lines derived from this program also exhibit good agronomic characteristics and high grain yield (Amaro et al., 2007; Arantes et al., 2010). However, there is a need for the incorporation of new sources of resistance to angular leaf spot in breeding programs, since none of the lines proved to be resistant to all of the strains evaluated. The recurrent selection program used 17 genotypes for the establishment of the base population, and, among them, ten are recognizable sources of resistance (AN512561, AND-277, Ouro Negro, Campuesto Negro Chimaltenango, CAL143, MAR-2, MAR-1, G5686, MA4.137, and Jalo). In general, all of the lines derived 
from this program exhibited a good level of resistance to the strains used, regardless of the selection cycle of the program. Therefore, it is possible that the level of resistance of the reference population of cycle 0 was already high, and that the progress to be obtained per cycle is small. This explains the small differences in the levels of resistance of the lines derived from the different selective cycles (Arantes et al., 2010), and confirms the predominance of quantitative inheritance in common bean resistance to angular leaf spot. Interestingly, the vertical genes fixed in the lines probably no should be in AND-277, Ouro Negro and Jalo cultivars, because vertical resistance in cultivar groups was no significant (Table 2).

In conclusion, our results show that recurrent selection is an efficient breeding strategy for the durable resistance of the common bean to angular leaf spot. Greater gains in successive selection cycles may be achieved by the incorporation of new sources of resistance. Therefore, the constant monitoring of the variability of the pathogen, and the use of artificial inoculations, are important. The use of molecular markers may be more effective in assisting recurrent selection programs than in the pyramiding of resistance genes, because this methodology will aid in the identification of vertical alleles of greater effect that are fixed in progenies over selective cycles.

\section{ACKNOWLEDGMENTS}

The authors thank the Coordenação de Aperfeiçoamento de Pessoal de Nível Superior, CAPES, Fundação de Amparo à Pesquisa do Estado de Minas Gerais, FAPEMIG, and Conselho Nacional de Desenvolvimento Cientifico e Tecnológico, CNPq, for a scholarship, and for funding the project.

\section{REFERENCES}

Adugna A (2004). Alternate approaches in deploying for disease resistance in crop plants. Asian J. Plant Sci. 3: 618-623. Akond ASMGM, Crawford H, Berthold J, Talukder ZI, et al. (2011). Minerals (Zn, Fe, Ca and Mg) and antinutrient (phytic acid) constituents in common bean. Am. J. Food Technol. 6: 235-243.

Amaro GB, Abreu AFB and Ramalho MAP (2007). Phenotypic recurrent selection in the common bean (Phaseolus vulgaris L) with carioca-type grains for resistance to the fungi Phaeoisariopsis griseola. Genet. Mol. Biol. 30: 584-588.

Arantes LO, Abreu AFB and Ramalho MAP (2010). Eight cycles of recurrent selection for resistance to angular leaf spot in common bean. Crop Breed. Appl. Biotechnol. 10: 232-237.

Balbi BP, Sanglard DA, Arruda KMA, Costa MR, et al. (2009). Characterization of Pseudocercospora griseola isolates collected in the state of Minas Gerais, Brazil. Ann. Rep. Bean Improv. Coop. 52: 56-57.

Beebe S (2010). Feijão Biofortificado. [http://www.harvestplus.org/publications]. Accessed November 27, 2010.

Borel JC, Ramalho MAP, Abreu AFB and Maia LGS (2011). Genetic control of the angular leaf spot reaction in common bean leaves and pods. Sci. Agric. 68: 661-664.

Buiate EAS, Souza EA, Vaillancourt L, Resende I, et al. (2010). Evaluation of resistance in sorghum genotypes to the causal agent of anthracnose. Crop Breed. Appl. Biotechnol. 10: 166-172.

Busogoro JP, Jijakli MH and Leproive P (1999). Virulence variation and RAPD polymorphism in African isolates of Phaeoisariopsis griseola (Sacc.) Ferr., the causal agent of angular leaf spot of common bean. Eur. J. Plant Pathol. 105: 559-569.

Chataika BYE, Bokosi JM, Kwapata MB, Chirwa RM, et al. (2010). Performance of parental genotypes and inheritance of Angular Leaf Spot (Phaeoisariopsis griseola) resistance in the common bean (Phaseolus vulgaris). Afr. J. Biotechnol. 9: 4398-4406.

Damasceno-Silva KJ, Souza EA, Sartorado A and Freire CND (2008). Pathogenic variability of isolates of Pseudocercospora griseola, the cause of common bean angular leaf spot, and its implications for resistance breeding. Phytopathology 156: $602-606$. 
Davide LM and Souza EA (2009). Pathogenic variability within race 65 of Colletotrichum lindemuthianum and its implications for common bean breeding. Crop Breed. Appl. Biotechnol. 9: 23-30.

Fao (2011). Undernourishment Around the World: Counting the Hungry: Latest Estimates. Available at [http://www.fao. org/documents/show_cdr.asp.htm]. Accessed May 2, 2011.

Garcia PAV, Carneiro MS and Sartorado A (2006). Phaeoisariopsis griseola virulence pattern and RAPD diversity. Ann. Rep. Bean Improv. Coop. 49: 209-210.

Gonçalves-Vidigal MCG, Cruz AS, Garcia A, Kami J, et al. (2011). Linkage mapping of the Phg-1 and Co-14 genes for resistance to angular leaf spot and anthracnose in the common bean cultivar AND 277. Theor. Appl. Genet. 122: 893-903.

Griffing B (1956). Concept of general and specific combining ability in relation to diallel crossing systems. Aust. J. Biol. Sci. 9: 463-493.

Habgood H (1970). Designation of physiological races of plant pathogens. Nature 227: 1268-1269.

Ishikawa FH, Ramalho MAP and Souza EA (2011). Common bean lines as potential differential cultivars for race 65 of Colletotrichum lindemuthianum. J. Plant Pathol. 93: 461-464.

Jara C, Castellano G and Mahuku G (2001). Estado actual y proyección de la investigación relacionada com la mancha angular del frijol (Phaeoisariopsis griseola). Fitopatol. Colomb. 25: 1-6.

Mahuku GS, Henríquez MA, Muñoz J and Buruchara RA (2002). Genetic variability within Phaeoisariopsis griseola from Central America and its implications for resistance breeding of common bean. Plant Pathol. 51: 594-604.

Mahuku GS, Iglesias AM and Jara C (2009). Genetics of angular leaf spot resistance in the Andean common bean accession G5686 and identification of markers linked to the resistance genes. Euphytica 167: 381-396.

Melo LC and Santos JB (1999). Identification of resistant genotypes considering polygenic systems in host-pathogen interaction. Genet. Mol. Biol. 22: 601-608.

Miklas PN, Kelly JD, Beebe SE and Blair MW (2006). Common bean breeding for resistance against biotic and abiotic stresses: From classical to MAS breeding. Euphytica 147: 105-131.

Mundt CC and Leonard KJ (1985). Effect of host genotype unit area on epidemic development of crown rust following focal and general inoculations of mixtures of immune and susceptible oat plants. Phytopathology 75: 1141-1145.

Nelson RR (1978). Genetics of horizontal resistance to plant diseases. Ann. Rev. Phytopathol. 16: 359-378.

Oblessuc PR, Baroni RM, Garcia AAF, Chioratto AF, et al. (2012). Mapping of angular leaf spot resistance QTL in common bean (Phaseolus vulgaris L.) under different environments. BMC Genet. 13: 1-9.

Parlevliet JE (1981). Disease Resistance in Plants and its Consequences for Plant Breeding. Plant Breeding II. The Iowa State University Press, Iowa.

Pastor-Corrales MA and Jara C (1995). La evolucion de Phaeoisariopsis griseola com el frijol comum en America Latina. Fitopatol. Colomb. 19: 15-22.

Pereira R, Souza EA, Barcelos QL and Abreu ABF (2013). Evaluation of resistance in common bean genotypes to the causal agent of angular leaf spot. Ann. Rep. Bean Improv. Coop. 56: 33-34.

Ragagnin VA, Souza TLPO, Sanglard DA, Arruda KMA, et al. (2009). Development and agronomic performance of common bean lines simultaneously resistant to anthracnose, angular leaf spot and rust. Plant Breed. 128: 156-163.

Ramalho MAP, Santos JB and Zimmermann MJO (1993). Genética Quantitativa em Plantas Autógamas: Aplicações ao Melhoramento do Feijoeiro. UFG, Goiânia.

Ramalho MAP, Abreu AFB and Santos JB (2007). Impact of angular leaf spot on grain yield of common bean lines. Ann. Rep. Bean Improv. Coop. 50: 97-98.

Sanglard DM, Damasceno JD, Souza TLPO, Balbi BP, et al. (2006). Pyramiding angular leaf spot resistance genes in a "carioca type" common bean. Ann. Rep. Bean Improv. Coop. 49: 197-198.

Sartorato A (2002). Identification of Phaeoisariopsis griseola pathotypes from five states of Brazil. Fitopatol. Bras. 27: 78-81.

Sartorato A (2007). Common bean genotypes resistant to angular leaf spot, rust and anthracnose. Ann. Rep. Bean Improv. Coop. 50: 103-104.

Sartorato A, Niestche S, Barros EG and Moreira MA (2000). RAPD and SCAR markers linked to resistance gene to angular leaf spot in common beans. Fitopatol. Bras. 25: 637-642.

Singh SP and Schwartz HF (2010). Breeding common bean for resistance to diseases: a review. Crop Sci. 50: 2200-2223. Statistical Analysis System Institute (2000). SAS Language and Procedures: Usage. Version 8.1. Cary, 1 CD-ROM.

Vanderplank JE (1963). Plant Diseases: Epidemics and Control. Academic Press, New York.

Vidigal PS, Gonçalves-Vidigal MC, Namayanja A, Nsanzabera F, et al. (2010). Molecular markers linked to angular leaf spot resistant genes in common bean accessions from eastern Africa and Brazil. Ann. Rep. Bean Improv. Coop. 53: 92-93. 